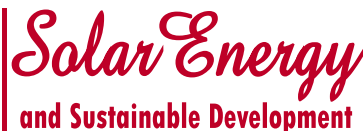 \\ Refereed, biannual scientific journal lssued by \\ Refereed, biannual scientific journal lssued by
Genter for Solar Energy Research and Studios
}

\section{On the Field Performance of PV Water Pumping System in Libya}

\author{
M. Sbeta', S. Sasi ${ }^{2}$ \\ Center for Solar Energy Research and Studies (CSERS). Tripoli-Libya \\ Email: sbita6 a wahoo.com \\ Email: sasi 1984saunahoo,com
}

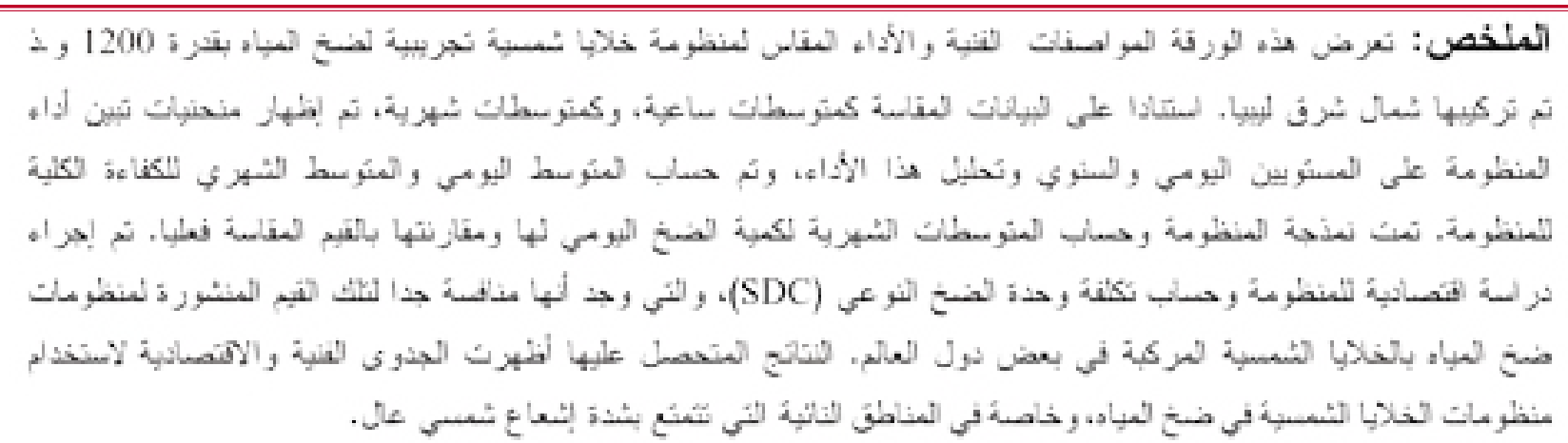

\begin{abstract}
This paper presents the measured performance of an experimental PV water pumping system of $1200 \mathrm{~W}_{\mathrm{p}}$ installed in the north-east of Libya. Both the monthly and hourly measured data of the system performance are presented and analised, and the over-all system efficiency has been calculated as monthly and daily averages. The monthly average output of the system has been estimated and compared with measured data. The economic analysis of the system has been carried out and the specific water discharge cost (SDC) has been determined, the obtained SDC was very competitive with the published SDC of the PV water pumping projects in some countries. The obtained results have demonstrated the technical and economic feasibility of using the PV systems for water pumping especially in the remote areas of high potential of solar insolation.
\end{abstract}

Keywords: PV array, ACDC inverter, Water pump, Specific water discharge cost.

\section{INTRODUCTION}

A drawback that may limit the utilization of PV systems is the need for electric energy storage unit. In case of stand-alone PV water pumping systems, this drawback can be overcome by replacing the electric energy storage unit with a water storage tank, which makes these systems more reliable and more economical compared to the battery-based stand-alone PV systems [3]. Recently, the PV water pumping systems became one of the main alternatives of power sources for providing water for different purposes, especially in the remote areas of high potential of solar insolation. In the framework of Centre for Solar Energy Research and Studies (CSERS) for promoting the use of PV systems for the development of rural areas in Libya, and carrying-out the $R / D$ activities on such systems under the local climatic conditions, a stand-alone PV water pumping system of $1200 \mathrm{~W}_{\mathrm{p}}$ has been installed in Mrada city in the north-east of Libya, as a pilot project with UNESCO. The project is aiming at providing water for livestock and evaluating 
the performance of the PV system under the local climatic conditions in order to build scientific bases for the wide use of these systems in Libya.

\section{WELL DATA}

The well is a shallow one used mainly for providing water for livestock. It is $1.2 \mathrm{~m}$ borehole diameter, $8 \mathrm{~m}$ total depth, and $6 \mathrm{~m}$ static level of water. It has a water storage tank of capacity $38 \mathrm{~m}^{3}$ located at $10 \mathrm{~m}$ from the borehole. The well is located in Mrada city (Long.: $19^{\circ} 12^{\prime} 21^{\prime \prime}$, Lat.: $29^{\circ} 15^{\prime} 22^{\prime \prime}$ ) which is about $700 \mathrm{~km}$ east of Tripoli. The monthly average of daily solar irradiation on the horizontal surface and mean ambient temperature for Mrada city are shown in table 1 [1.2]. The demand for water is not well defined; it is generally high in the summer season and decreases considerably in the winter season. It has been estimated that $50 \mathrm{~m}^{3} /$ day of water as a monthly average in the summer season is adequate to fulfil the demand.

Table 1: Monthly averages of solar radiation and ambient temperature data.

\begin{tabular}{|c|c|c|}
\hline Month & $\begin{array}{l}\text { Solar Irradiation } \\
\left(\mathrm{kWh} / \mathrm{m}^{2} \text { day }\right)\end{array}$ & $\begin{array}{c}\text { Ambient emp. } \\
\left({ }^{\circ} \mathrm{C}\right)\end{array}$ \\
\hline Jan. & 3.7 & 19.4 \\
\hline Feb. & 4.6 & 21.6 \\
\hline Mar. & 5.5 & 25.5 \\
\hline Apr. & 6.6 & 30.1 \\
\hline May & 6.8 & 34.1 \\
\hline Jun. & 7.3 & 37.5 \\
\hline Jul. & 7.2 & 36.9 \\
\hline Aug. & 6.7 & 36.7 \\
\hline Sep. & 5.8 & 33.7 \\
\hline Oct. & 4.9 & 30.2 \\
\hline Nov. & 3.9 & 25.4 \\
\hline Dec. & 3.5 & 20.6 \\
\hline
\end{tabular}

\section{DESCRIPTION OF PV SYSTEM}

The PV system consists of a PV array of total power $1200 \mathrm{Wp}$ which provides the electric power to an $\mathrm{AC}$ submersible water pump of $950 \mathrm{~W}$ rated power through a special DC/AC inverter of $1500 \mathrm{~W}$ rated power. The system is equipped with a data acquisition system for auto measuring and logging of both the climatic and electric parameters. The system lay-out is shown in figure 1.

\subsection{PV array}

The PV generator consists of two strings connected in parallel; each string is formed from eight PV modules connected in series. The PV module is of multi-crystalline silicon solar cells (encapsulated in tempered glass, EVA and tedlar/polyester backing) of $75 \mathrm{Wp}$ under STC and $12 \mathrm{~V}$ nominal voltage. The 16 PV modules (1200Wp) are mounted on four modular and adjustable tilt angle supporting structures fabricated from aluminium. The tilt angle was optimized and set at 15 degree to the south [4].

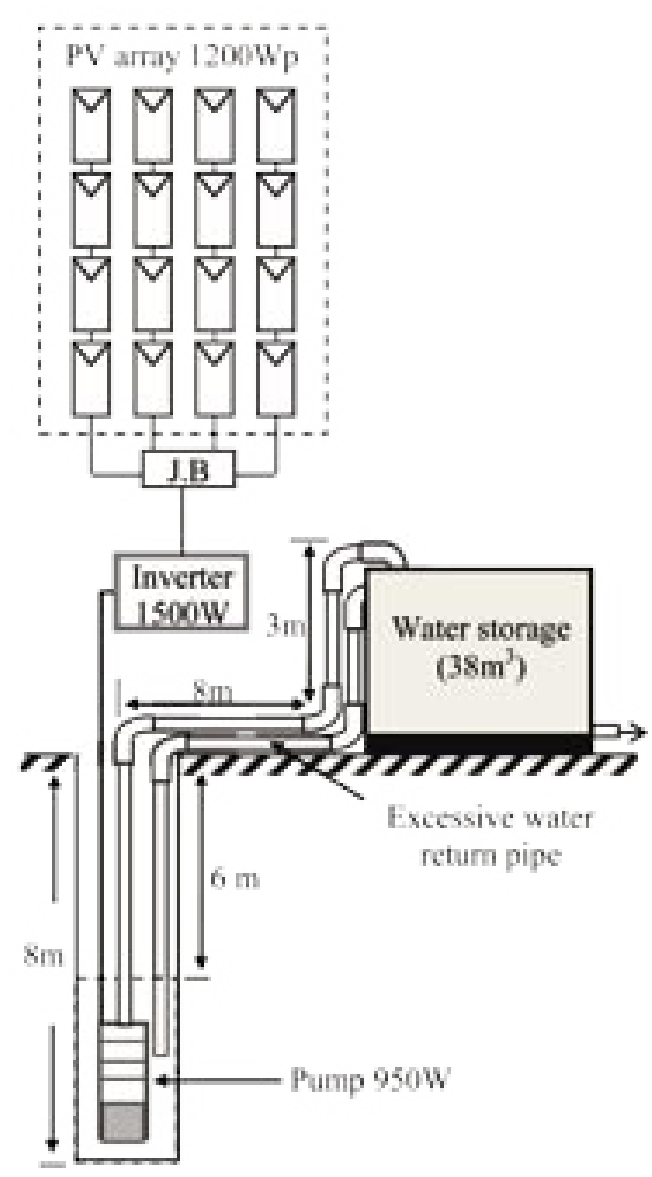

Figure 1: Lay-out of PV water pumping system

\subsection{AC/DC Inverter}

The DC output voltage of the PV generator is converted to an $\mathrm{AC}$ voltage to power the motor of water pump via variablevoltage variable-frequency (VVVF) inverter 
of $1500 \mathrm{~W}$. The inverter can accept a DC voltage of level ranges from 105 to 120 VDC, and generates a three-phase $\mathrm{AC}$ voltage of level varies from 8 to $80 \mathrm{VAC}$ and frequency varies from 6 to $60 \mathrm{~Hz}$. The output voltage of the inverter varies in its level and frequency as a response to the variation in the output power of PV array (i.e. the variation in solar irradiation intensity). This facility leads to maximizing the pumping flow rate in low solar irradiation periods. In addition, the inverter has the facilities of dry running protection and overload protection.

\subsection{Motor and water pump}

The water pump is a stainless steel submersible pump which is run by an integrated three-phase $80 \mathrm{VAC}$ brushless electric motor of $950 \mathrm{~W}$ rated power, $60 \mathrm{~Hz}$ rated frequency, and $3480 \mathrm{cycle} / \mathrm{s}$ rated running speed. Both the pump and the inverter are made of the same company (Grundfos company), which guarantees the best matching between them and highest overall performance

\subsection{Data acquisition system}

In order to follow up the field performance of the PV water pumping system, a data acquisition system has been used for auto measuring and logging with interval of 10 minutes for the following parameters:

- Solar irradiation at tilt angle of PV array

- Ambient temperature

- Wind speed

- PV array output de voltage

- PV array output de current

- PV modules temperature

- Water pumping flow rate

\section{PERFORMANCE OF PV SYSTEM}

\subsection{Estimated performance of system}

Based on the well data and technical specifications of the components of PV system, the monthly average of daily pumped water has been estimated using the equation 1 [5], and the estimated results are shown in figure 2.

$\mathrm{Q}=\frac{\mathrm{P}_{\mathrm{a}} \mathrm{G}_{\mathrm{i}} \eta_{\mathrm{imv}} \eta_{\operatorname{mp}} \mathrm{F}\left[1-\beta\left(\mathrm{T}_{\mathrm{c}}-\mathrm{T}_{\mathrm{a}}\right)\right]}{2.725 \mathrm{H}_{\mathrm{t}}}$

The PV module temp. can be calculated using equation 2 [6]

$\mathrm{T}_{\mathrm{c}}=\mathrm{T}_{\mathrm{a}}+2.7 \mathrm{G}_{\mathrm{t}}$

Where:

Q: the monthly average of daily pumped water $\left(\mathrm{m}^{3} / \mathrm{day}\right)$.

$\mathrm{P}_{3}$ : total power of $\mathrm{PV}$ array (W).

$\mathrm{G}_{1}$ : monthly average of daily solar irradiation on the tilted surface of PV array $\left(\mathrm{kWh} / \mathrm{m}^{2}\right.$ day).

$\eta_{i n v}:$ inverter efficiency.

$\eta_{\text {mpp: }}$ motor/pump efficiency.

F: factor considers the mismatch between PV modules, loss in cables and wires, and threshold solar irradiation to start the pump.

$\beta$ : temperature coefficient $\left(0.005 /{ }^{\circ} \mathrm{C}\right)$.

$\mathrm{T}_{\mathrm{a}}$ : monthly average of daily mean ambient temperature $\left({ }^{\circ} \mathrm{C}\right)$.

$\mathrm{T}_{\mathrm{c}}$ : monthly average of daily mean PV module temp. $\left({ }^{\circ} \mathrm{C}\right)$.

$\mathrm{H}_{4}$; total effective height of pumping (m).

\subsection{Measured performance of system}

The PV system is adjusted to operate automatically without stop whenever the solar insolation is available. To avoid the waste of water due to over-pumping, a water pipe has been installed to return the surplus of pumped water from the storage tank back to the well (see figure 1). The system is up to date working automatically for six years without stop. During this period, the beneficiaries were very satisfied with the system performance and reliability, where, in contrast to the case for the diesel generator, it has no need for a daily followup, fuel supply and frequent maintenance.

Figure 2 shows the measured data compared with the estimated data of the monthly average of daily pumped water. The estimated system output is higher 
because the estimation model is a rough one and it doesn't consider some specifics of the system components. For more reliable results, a sophisticated simulation computer programs should be used.

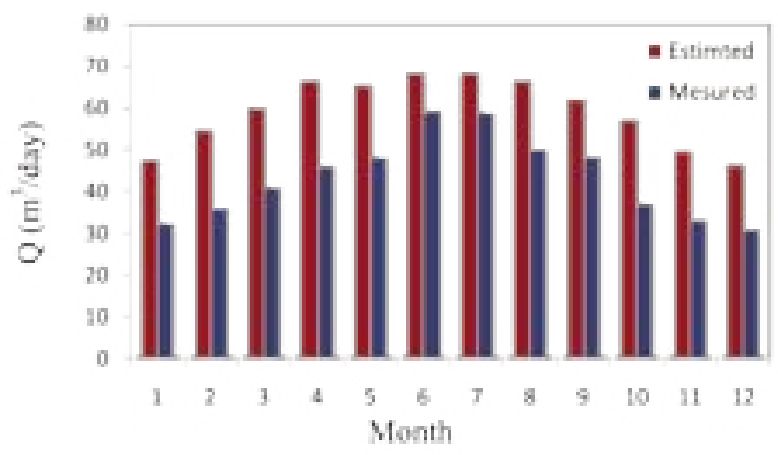

Figure 2: The measured and estimated data of pumped water

Figure 3 demonstrates the instantaneous system performance on a sunny day in December. According to the performance record of this day, the pump starts working at one hour after the sunrise, and at this time, the PV array output power is $145 \mathrm{~W}$ (corresponding to $160 \mathrm{~W} / \mathrm{m}^{2}$ of solar irradiation) which is equivalent to $15 \%$ of pump motor rated power. It has been found that threshold power of pump causes a loss of $5-9 \%$ of the available solar energy throughout the year; the loss is higher in the months of lower level of solar irradiation.

The variable-voltage variable-frequency facility of system inverter provides more efficient operation of pump motor and best use of available power coming from the PV array. This feature contributes to reducing the threshold power of the pump and maximizing the use of available solar energy. As a result of this feature, the pump flow rate increases logarithmically with the increase of solar irradiation intensity as shown in figure 3 -D. The pump flow rate reaches $75 \%$ of its rated value at $50 \%$ of pump rated power.

Based on the measured data, and by finding the hydraulic energy, $\mathrm{E}_{\mathrm{h}}(\mathrm{kWh})$, corresponding to the measured quantity of pumped water using equation 3 [6], the yearly average of overall system efficiency has been calculated, and the value of $2.2 \%$ has been found.
$\mathrm{E}_{\mathrm{h}}=2.275 \mathrm{QH}$

Where:

Q: the monthly average of daily pumped water $\left(\mathrm{m}^{3} /\right.$ day $)$.

$\mathrm{H}_{4}$ : total effective height of pumping (m).

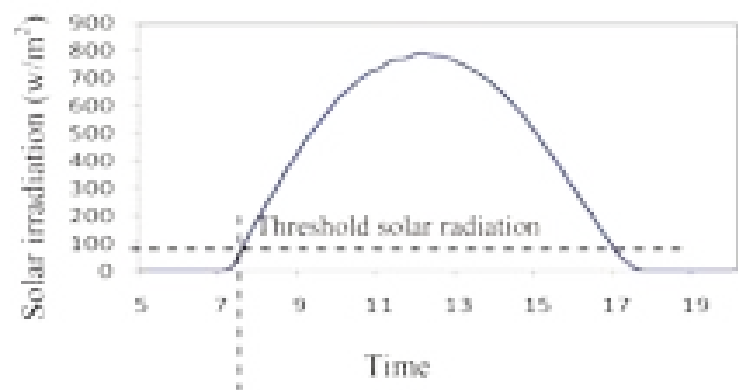

(A)

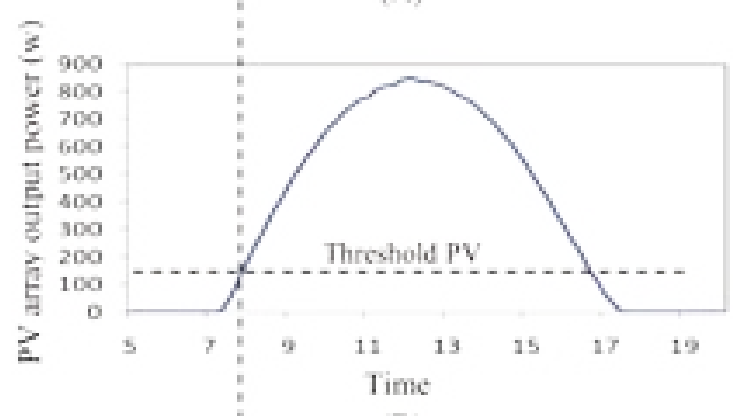

(B)

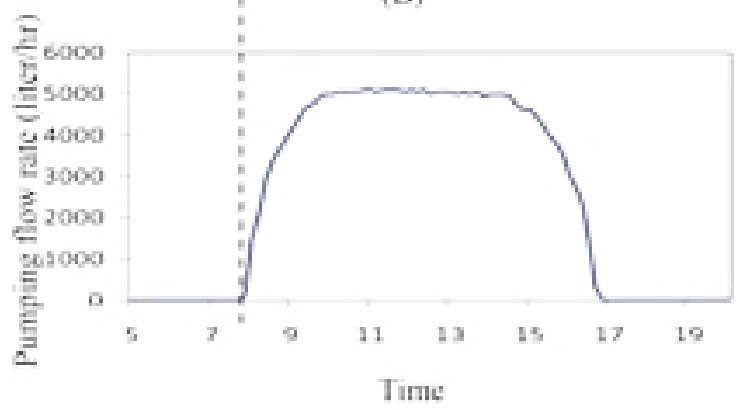

(C)

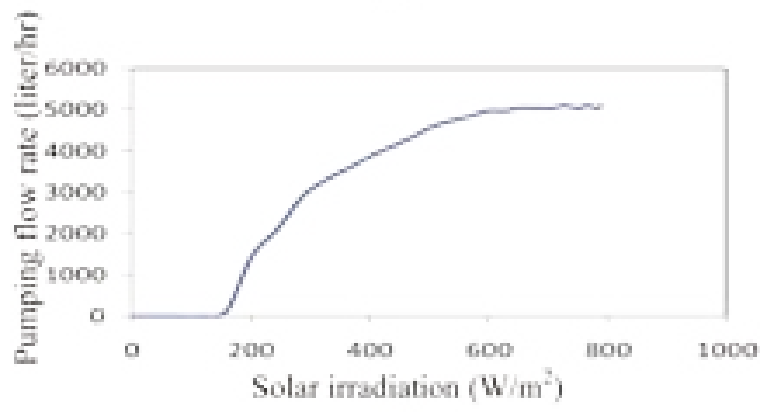

(D)

Figure 3: Performance record of a sunny day in December

The system efficiency depends on many factors interrelated to each other such as: solar irradiation intensity, pump threshold power, and PV module temperature, and therefore no general certain trend has been 
found for the change of efficiency throughout the year. In spite of that, it has been noticed that for a semi-equal ambient temperature period, the over-all system efficiency was higher in the day of lower solar irradiation as shown in figure 4 which demonstrates the daily change in the over-all system efficiency with the change of solar irradiation in December. The logarithmic increase of pump flow rate versus the increase of solar irradiation intensity is a major issue behind this behaviour.

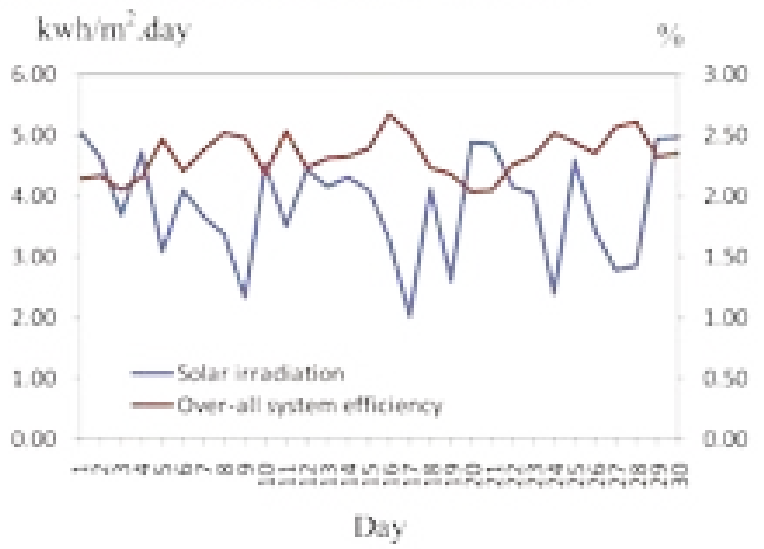

Figure 4: Daily over-all system efficiency and solar irradiation in December

As it is shown in figure $3-\mathrm{D}$, the pumping flow rate reaches about $85 \%$ of its rated value at $700 \mathrm{~W} / \mathrm{m}^{2}$ of solar irradiation intensity. The pumping flow rate increases by $25 \%$ when the solar irradiation increases from $500 \mathrm{~W} / \mathrm{m}^{2}$ to $700 \mathrm{~W} / \mathrm{m}^{2}$, while it increases by only less than $10 \%$ when the solar irradiation increases from $700 \mathrm{~W} / \mathrm{m}^{2}$ to $900 \mathrm{~W} / \mathrm{m}^{2}$. As a result, the over-all system efficiency is about $2.6 \%$ and $1.7 \%$ at 500 $\mathrm{W} / \mathrm{m}^{2}$ and $900 \mathrm{~W} / \mathrm{m}^{2}$ of solar irradiation respectively.

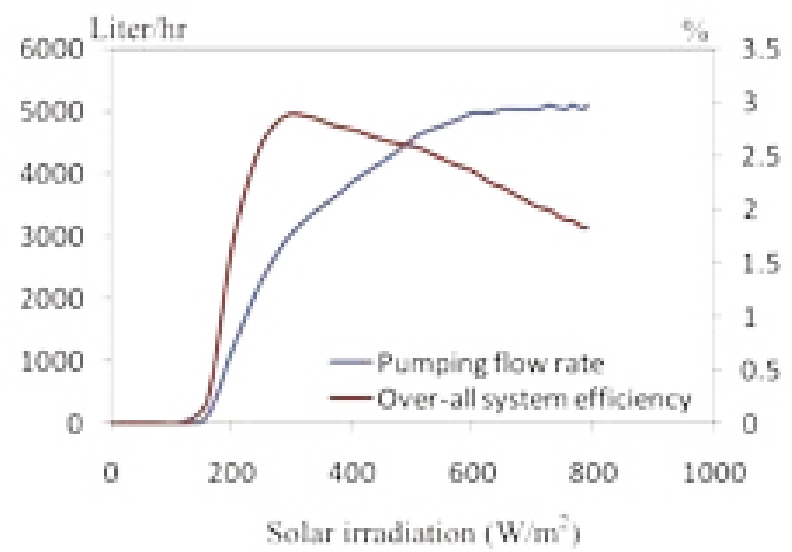

Figure 5: Pumping flow rate and over-all system efficiency
Figure 5 demonstrates the change in pumping flow rate and over-all system efficiency as a function of solar irradiation intensity of a sunny day in December, the over-all system efficiency reaches its maximum value at relatively low level of solar irradiation (about $200 \mathrm{~W} / \mathrm{m}^{2}$ ) then it declines linearly with the increase of solar radiation.

\section{ECONOMIC ANALYSIS}

The comparison of economic feasibility among the different methods of water pumping can be determined according to the cost of unit volume $\left(\cos t / \mathrm{m}^{3}\right)$ of the pumped water along the expected life time of the pumping system. The cost of unit volume depends on many factors such as the daily pumping quantity, the pumping head, and the demand profile of water. For more fair comparison, the criterion of cost of unit volume of pumped water to the unit of pumping height $\left(\cos t / \mathrm{m}^{3} \cdot \mathrm{m}\right)$ is mostly used; this criterion is called the specific water discharge cost (SDC).

The specific water discharge cost of the PV water pumping system has been determined using the equations 4-8 [7, 12] under the following assumptions:

- Expected life time of the system $=20$ years

- Expected life time of the PV modules $(\mathrm{N})=20$ years

- Expected life time of the inverter $(\mathrm{n})=$ 10 years

- Expected life time of the water pump/motor $(n)=10$ years

- Yearly interest rate (i) $=\| \%$

- Increase in components cost $=0$

- Yearly maintenance cost $=1 \%$ of the initial system cost $\left(\mathrm{C}_{\mathrm{T}}\right)$.

$$
\begin{aligned}
& \mathrm{K}_{\mathrm{a}}=\frac{1-(1+\mathrm{i})^{-\mathrm{N}}}{\mathrm{i}} \\
& \mathrm{K}_{\mathrm{r}}=\frac{1}{(1+\mathrm{i})^{\mathrm{n}}} \\
& \mathrm{C}_{\mathrm{TT}}=\mathrm{C}_{\mathrm{T}}+0.1 \mathrm{C}_{\mathrm{T}} \mathrm{K}_{\mathrm{a}}+\mathrm{C}_{\mathrm{T}} \mathrm{K}_{\mathrm{r}}
\end{aligned}
$$


$\mathrm{C}_{\mathrm{TA}}=\frac{\mathrm{C}_{\mathrm{TT}}}{\mathrm{K}_{\mathrm{a}}}$

$\mathrm{SDC}=\frac{\mathrm{C}_{\mathrm{TA}}}{\mathrm{Q}_{\mathrm{y}} \mathrm{H}_{\mathrm{t}}}$

Where:

$\mathrm{K}_{\mathrm{a}}$ : yearly factor of periodic cost.

$\mathrm{K}_{\mathrm{r}}$ : yearly factor of future cost.

$\mathrm{C}_{\mathrm{r}}$ : cost of inverter and pump.

$\mathrm{C}_{T \mathrm{~T}}$ : total system cost for the entire its expected life time.

$\mathrm{C}_{\mathrm{TA}}$ : yearly cost.

$Q_{y}$ : yearly pumped water.

The results of SDC of the system are shown in table 2. The initial cost of the system is 12583 USD, and the relative distribution of system components cost is shown in Figure 6.

As a comparison with the published SDC $\left(\mathrm{USD} / \mathrm{m}^{4}\right)$ of the PV water pumping projects in some countries, in Jordan was $3.7 \times 10^{-3}$ [8], Tunisia $7-20 \times 10^{-3}[9]$, Chile $9-20 \times 10^{-3}$ [10], Yemen $15 \times 10^{-3}[11]$, and German program (for some development countries) $10 \times 10^{-3}[5]$, and about $20-30 \times 10^{-3}$ in case of using the diesel generators in water pumping $[10,11]$.

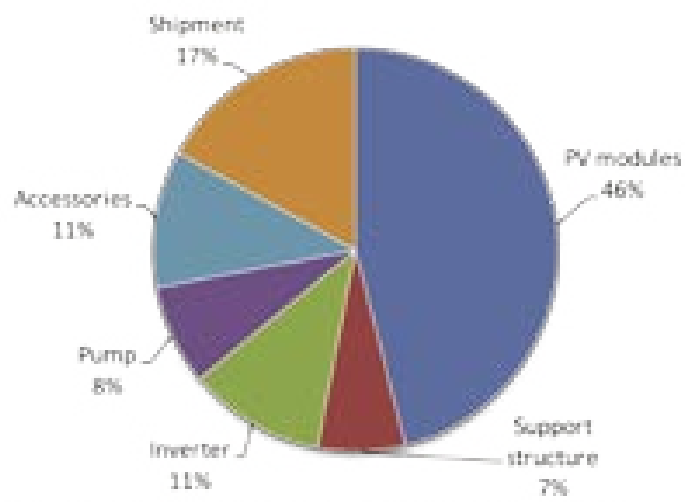

Figure 6: Relative distribution of system components cost

Table 2: The calculation results of SDC

\begin{tabular}{c|c}
\hline $\mathrm{C}_{\mathrm{TA}}(\mathrm{USD})$ & 1704 \\
$\mathrm{Q}_{\mathrm{y}}\left(\mathrm{m}^{3} / \text { year }\right)^{*}$ & 15763 \\
$\mathrm{SDC}\left(\mathrm{USD} / \mathrm{m}^{4}\right)$ & $10.8 \times 10^{-3}$ \\
\hline - The measured value &
\end{tabular}

\section{CONLUSION}

Based on the practical experience, the use of PV systems for water pumping in remote areas is preferred than the use of diesel generator due to some advantages of the PV systems among of which are; high reliability, fully automatic operation, no need for fuel supply, and the little need for maintenance.

The variable-voltage variable-frequency (VVVF) facility of the inverter has a significant contribution in raising the overall efficiency of PV water pumping systems, and this facility well compensates the negative effect of high temperature which reduces the PV array efficiency.

In case of using VVVF inverters, the rated power of pump motor should be comparable to the rated power of PV array in order to minimize the loss of available solar irradiation and raise the over-all system efficiency.

The technical and economical assessment of PV systems requires a long term monitoring of the operation of these systems. Using good designed data acquisition system is of immense value to the engineers to evaluate the PV system using reliable and detailed measured data.

\section{REFERENCES}

[1] Mean monthly solar radiation measurements during the period of 1981-1988, information department, Centre for Solar Energy Studies, Tripoli-Libya.

[2] Mean monthly temperature data during the period of 1945-1984, meteorological department, internal report, TripoliLibya.

[3] M. Hamed, M. Sbeta, H. Lamen, "On the performance of experimental PV water pumping in Mrada/Libya", International Arabic Conference on Solar Energy, Tripoli-Libya, 2004.

[4] K. Aghah, M. Sbeta, "On the sizing parameter for stand-alone solar energy studies". Applied Solar Energy, 2000. 
[5] Andrea Hahn, "Lessons learned from an international photovoltaic pumping programs", $2^{\text {nd }}$ world conference and exhibition on photovoltaic solar energy conversion, Vienna- Austria, 610 July 1998.

[6] J. Kenna, B. Gillett, "Solar water pumping", Intermediate Technology publication, UK, 1985.

[7] T. Markvart, "Solar electricity", 1995.

[8] Marwan Mahmoud, Khaled Daoud, Fayez Kilani, "Experement results and techno-economic feasibility of using photovoltaic generators instead of diesel engines for water pumping from rural and desert wells in Jordan".
[9] George Scherl, "Objectives and results of the international programme for field testing of photovoltaic water pumping, on the examples of the Tunisian programme", Presentation in Tripoli - Libya, Nov. 1996.

[10] Eduordo Lorenzo, "Solar Electricity Engineering of Photovoltaic Systems", 1994.

[11] Christer Nymen, "First experience of water pumping systems in Yamen, $16^{\text {th }}$ European photovoltaic energy conference", Clasgow - U.K, 1-5 May 2000 .

[12] Andrea Hahn, Reinhold Schmidt, "Irrigating with sun-generating income with photovoltaic water pumping", $17^{\text {th }}$ European photovoltaic solar energy conference, Munich - Germany, 22-26 Oct. 2001. 